\title{
Hubungan Sikap Belajar dan Kebiasaan Belajar dengan Hasil Belajar Mata Pelajaran Teknologi Dasar Otomotif (TDO)
}

\section{Fauzan $^{1 *}$, Hasan Maksum ${ }^{2}$, Wawan Purwanto ${ }^{3}$, Eko Indrawan ${ }^{4}$}

1234 Universitas Negeri Padang, Padang, Indonesia

*e-mail: fauzanmpdt@gmail.com

\begin{abstract}
Abstrak
Kurangnya minat siswa dalam belajar membuat hasil belajar siswa dibawah rata-rata nilai ketuntasan minimal. Penelitian ini bertujuan untuk menganalisis hubungan sikap belajardan kebiasaan belajar dengan hasil belajar mata pelajaran Teknologi Dasar Otomotif (TDO) Kelas X TAB. Jenis penelitian ini adalah kuantitatif melalui pendekatan korelasional. Populasi dalam penelitian ini adalah seluruh siswa kelas $X$ berjumlah 36 orang siswa. Instrumen yang digunakan untuk mengumpulkan data pada penelitian ini adalah angket. Teknik yang digunakan untuk menganalisis data yaitu uji normalitas, reliabilitas, dan uji prasyarat data. Hasil penelitian ini menunjukkan bahwa terdapat hubungan yang positif dan signifikan sikap belajar dengan hasil belajar TDO siswa kelas X TAB berada pada kategori kuat. Kontribusi sikap belajar terhadap hasil belajar TDO siswa kelas X TABK sebesar $56,1 \%$. Hasil penelitian ini menunjukkan bahwa terdapat hubungan yang positif dan signifikan kebiasaan belajar dengan hasil belajar TDO siswa kelas X TAB berada pada kategori kuat. Kontribusi kebiasaan belajar terhadap hasil belajar TDO siswa sebesar $32,4 \%$. Dapat disimpulkan bahwa kebiasaan belajar dengan hasil belajar berpengaruh pada hasil belajar siswa.
\end{abstract}

Kata kunci: sikap dan kebiasaan belajar, hasil belajar siswa

\begin{abstract}
Lack of student interest in learning makes student learning outcomes below the average minimum completeness value. This study aims to analyze the relationship between learning attitudes and learning habits with learning outcomes in the subjects of Basic Automotive Technology (TDO) Class X TAB. This type of research is quantitative through a correlational approach. The population in this study were all students of class $X$ totaling 36 students. The instrument used to collect data in this study was a questionnaire. The techniques used to analyze the data were normality, reliability, and data prerequisite tests. The results of this study indicate that there is a positive and significant relationship between learning attitudes and learning outcomes of TDO class $X$ TAB students in the strong category. The contribution of learning attitudes to the learning outcomes of class X TABK students' TDO was $56.1 \%$. The results of this study indicate that there is a positive and significant relationship between study habits and the learning outcomes of TDO class X TAB students in the strong category. The contribution of learning habits to student TDO learning outcomes was $32.4 \%$. It can be concluded that learning habits and learning outcomes have an effect on student learning outcomes.
\end{abstract}

Keywords: attitudes and learning habits, student learning outcomes

\footnotetext{
${ }^{*}$ Corresponding author. 


\section{Pendahuluan}

Keberhasilan dari suatu kegiatan pembelajaran dapat dilihat dari hasil belajar setelah mengikuti pembelajaran (Nurlia, Hala, Muchtar, Jumadi, \& Taiyeb, 2017; Yesiana, Gading, \& Riastini, 2016). Dari hasil belajar tersebut juga dapat dilihat berhasil tidaknya pendidikan pada suatu lembaga pendidikan. Untuk mendapatkan hasil belajar yang baik maka perlu memperhatikan beberapa tahapan dan proses dalam pembelajaran. Hasil belajar merupakan hasil yang dicapai dalam bentuk angka-angka atau skor setelah diberikan tes hasil belajar pada setiap akhir pembelajaran (Izati, Wahyudi, \& Sugiyarti, 2018; Kurnia, Damayani, \& Kiswoyo, 2019). Penguasaan siswa terhadap materi pembelajaran akan terlihat dari nilai yang diperoleh oleh siswa selama mengikuti pembelajaran. Diharapkan siswa mendapatkan hasil belajar diatas Standar Ketuntasan Belajar Minimal (SKBM) atau Kriteria Ketuntasan Minimal (KKM) kurikulum 2004 yang sesuai.

Namun permasalahan yang terjadi saat ini yaitu masih banyak siswa yang mendapatkan hasil belajar yang rendah (Lestari, Kristiantari, \& Ganing, 2017; Zahro, Degeng, \& Mudiono, 2018). Permasalahan ini juga ditemukan pada salah satu sekolah menengah atas (SMA). Berdasarkan hasil observasi yang dilakukan di SMKN 2 Payakumbuh, hasil belajar siswa kelas X TAB khususnya untuk mata pelajaran TDO ditemukan lebih $97,22 \%$ siswa mendapatkan nilai dibawah KKM $(<75)$ sedangkan menurut standar kompetensi 2013, siswa dikategorikan lulus memperoleh nilai sesuai standar kompetensi yang ditetapkan. Hal ini disebabkan oleh beberapa faktor yaitu kebiasaan dan sikap belajar siswa yang rendah. Sikap belajar siswa yang cenderung acuh tak acuh terhadap mata pelajaran yang dipelajari, serta kurangnya rasa ingin tahu siswa pada materi yang diajarkan salah satu penyebab rendahnya hasil belajar siswa. Siswa terlihat jarang mengajukan pertanyaan dan menjawab pertanyaan saat pembelajaran. Selain itu, siswa kurang disiplin belajar dan memiliki cara belajar yang kurang tepat saat belajar di rumah. Siswa juga jarang mengerjakan tugas dengan tepat waktu. Siswa kurang mempersiapkan diri menghadapi ujian sehingga memperoleh Ujian di bawah KKM. Kurangnya motivasi siswa dalam belajar berpengaruh pada hasil belajar siswa (Saputra \& Andrizal, 2018; Sutardi \& Sugiharsono, 2016).

Ada beberapa faktor yang mempengaruhi hasil belajar siswa rendah yaitu faktor internal adalah faktor yang berasal dari dalam diri siswa itu sendiri yang meliputi motivasi, kreativitas, bakat, sikap, gaya belajar, kemampuan, minat dan konsep diri siswa itu sendiri (Nurlia et al., 2017; Sutrisno \& Siswanto, 2016). Faktor eksternalnya adalah faktor yang berasal dari luar diri siswa hal ini dapat berupa disiplin, sarana prasarana, situasi lingkungan baik itu lingkungan keluarga, sekolah maupun lingkungan masyarakat (Ferdian, Maryam, \& Selamat, 2018; Saputra \& Andrizal, 2018). Sesuai faktor-faktor yang telah mempengaruhi hasil belajar maka dalam penelitian ini lebih mengarah kepada sikap dan kebiasaan belajar terhadap hasil belajar. Sikap yang cenderung acuh tak acuh terhadap mata pelajaran yang dipelajari, kurangnya rasa ingin tahu siswa pada materi yang diajarkan hal ini terlihat pada proses belajar dirumah, siswa terlihat jarang mengajukan pertanyaan, menjawab pertanyaan. Kebiasaan belajar siswa masih banyak yang kurang baik, hal ini terlihat dari kurangnya disiplin belajar di rumah, memiliki cara belajar yang kurang tepat, penggunaan waktu belajar kurang efektif, kurang mempersiapkan diri menghadapi ujian dan jarang mengerjakan tugas dengan tepat waktu. Diperlukan sikap positif pada siswa untuk meningkatkan hasil belajar siswa.

Sikap siswa yang positif guru merupakan pertanda awal yang baik bagi proses belajar siswa. Untuk mengantisipasi kemungkinan munculnya sikap negatif siswa, guru dituntut untuk terlebih dahulu menunjukkan sikap positif terhadap dirinya sendiri dan terhadap mata pelajaran yang menjadi haknya (Agathi Dian, Kristiantari, \& Ganing, 2015; Junianto \& Wagiran, 2013). Dalam hal bersikap positif terhadap mata pelajarannya, seorang guru sangat dianjurkan untuk senantiasa menghargai dan mencintai profesinya. Guru yang demikian tidak hanya menguasai bahan-bahan yang terdapat dalam bidang 
studinya, tetapi juga mampu meyakinkan para siswa akan manfaat bidang studi itu bagi kehidupan mereka. Dengan meyakini manfaat bidang studi tertentu, siswa akan merasa membutuhkannya, dan dari perasaan butuhitulah diharapkan muncul sikap positif terhadap bidang studi tersebut sekaligus terhadap guru yang mengajarkannya (Rijal \& Bachtiar, 2015). Maka sangat penting bagi siswa untuk menumbuhkan sikap belajar yang positif agar mendapat hasil belajar yang baik.

Hasil belajar merupakan tolak ukur yang digunakan untuk menentukan tingkat keberhasilan siswa dalam memahami konsep dalam belajar. Apabila sudah terjadi perubahan tingkah laku seseorang, maka seseorang sudah dikatakan berhasil dalam belajar. Hasil belajar adalah kemampuan-kemampuan yang dimiliki siswa sebagai akibat perbuatan belajar dan dapat diamati melalui penampilan siswa (Kadek, 2017; Santra, Wibawa, \& Rati, 2018). Dalam sistem pendidikan nasional rumusan tujuan pendidikan, baik tujuan kurikuler maupun tujuan insruksional, menggunakan klasifikasi hasil belajar dari Benyamin Bloom yang secara garis besar membaginya menjadi tiga ranah, yakni ranah kognitif, ranah afektif, dan ranah psikomotor (Sujana, 2019; Yayuk \& Sugiyono, 2019). Ketiga ranah tersebut menjadi objek penilaian hasil belajar. Diantara ketiga ranah itu, ranah kognitif yang paling banyak dinilai oleh para guru di sekolah karena berkaitan dengan kemampuan para siswa dalam menguasai isi bahan pengajaran.

Untuk memperoleh hasil belajar yang baik, terdapat banyak faktor yang mempengaruhinya. Adapun faktor-faktor tersebut ada yang berasal dari dalam diri siswa, ada juga yang berasal dari luar diri siswa. Faktor Eksternal Siswa (faktor dari luar siswa) yakni lingkungan sosial, non sosial, dan faktor pendekatan belajar. Faktor Internal (faktor dari dalam siswa), yakni keadaan/kondisi jasmani dan rohani. Faktor yang berasal dari dalam diri siswa sendiri meliputi dua aspek yang meliputi aspek fisiologis dan psikologis. Aspek Fisiologis yaitu kondisi umum jasmani dan tegangan otot yang menandai tingkat kebugaran organ-organ tubuh dan sendi-sendinya, dapat mempengaruhi semangat dan intensitas siswa dalam mengikuti pelajaran (Maesaroh, 2013; Rustiana, 2011). Kondisi organ tubuh yang lemah, apalagi jika disertai sakit kepala misalnya, dapat menurunkan kualitas kognitif sehingga materi yang dipelajarinya pun kurang atau tidak berbekas. Aspek Psikologis yang meliputi intelegensi siswa dan sikap siswa.

Penelitian yang dilakukan oleh Leonard \& U.S (2010) menyatakan bahwa adanya pengaruh antara sikap siswa terhadap hasil belajar siswa. Siswa yang memiliki kepercayaan dan cara pandang positif maka akan meningkatkan hasil belajar siswa. Penelitian yang dilakukan oleh Riwahyudin (2015) menyatakan bahwa sikap siswa berpengaruh positif terhadap hasil belajar sisa sekolah dasar. Sikap positif yang dimiliki siswa dalam belajar menyebabkan hasil belajar yang baik. Selain itu, minat belajar juga berpengaruh pada hasil belajar siswa. Penelitian yang dilakukan oleh Usfandi (2019) menyatakan terdapat pengaruh sikap dan minat siswa terhadap hasil belajar siswa. Semakin tinggi sikap dan minat siswa terhadap materi pembelajaran maka akan mempengaruhi hasil belajar siswa yang meningkat.

Penelitian ini bertujuan untuk menganalisis hubungan sikap belajar dan kebiasaan belajar dengan hasil belajar mata pelajaran Teknologi Dasar Otomotif (TDO) Kelas X TAB. Diharapkan sikap belajar dan kebiasaan belajar siswa yang baik akan meningkatkan hasil belajar siswa pada mata pelajaran Teknologi Dasar Otomotif (TDO).

\section{Metode}

Jenis penelitian yang dipakai yaitu kuantitatif melalui pendekatan korelasional. Analisis yang digunakan adalah analisis korelasi ganda untuk mengetahui pengaruh variabel secara bebas dan terikat tanpa memberikan perlakuan terhadap responden dan subjek penelitian. Tempat penelitian adalah di SMKN 2 Payakumbuh pada tahun ajaran 2020/2021. Populasi dalam penelitian ini adalah seluruh siswa kelas X di SMKN 2 Payakumbuhan yang terdiri dari 1 kelas dengan jumlah 36 orang siswa. Instrumen yang digunakan untuk mengumpulkan data pada penelitian ini adalah angket. 
Teknik pengambilan sampel dalam penelitian ini adalah sampling total. Variabel yang digunakan dalam penelitian ini yaitu: variabel independent/bebas diantanya sikap belajar dan motivasi belajar, Variabel dependent yang digunakan yaitu hasil belajar TDO. Data adalah sekumpulan bukti empiris yang didapat dari suatu proses pencarian yang diproses hingga menghasilkan informasi yang dibutuhkan. Data primer yaitu data yang secara langsung didapat dari hasil penyebaran angket kepada responden, yaitu siswa kelas X TAB di SMKN 2 Payakumbuh pada tahun 2020/2021 dan data sekunder yaitu nilai MID Semester mata pelajaran TDO di SMKN 2 Payakumbuh. Teknik yang digunakan untuk menganalisis data yaitu uji normalitas, reliabilitas, dan uji prasyarat data.

\section{Hasil dan Pembahasan}

Hasil penelitian ini menunjukkan bahwa terdapat hubungan yang positif dan signifikan sikap belajar dengan hasil belajar TDO siswa kelas X TAB SMK Negeri 2 Payakumbuh yang berada pada kategori kuat. Kontribusi sikap belajar terhadap hasil belajar TDO siswa kelas X TABK SMK Negeri 2 Payakumbuh sebesar 56,1\%. Proses sangat berguna dalam menanamkan sikap belajar kepada siswa. Sikap belajar berhubungan positif dan signfikan terhadap hasil belajar mata pelajaran Teknologi Dasar Otomotif Siswa kelas X TAB di SMKN 2 Payakumbuh yang kuat sebesar 0,749. Sikap belajar yang baik akan mampu meningkatkan hasil belajar siswa, Kebiasaan belajar berhubungan positif dan signifikan terhadap hasil belaajr mata pelajaran Teknologi Dasar Otomoti Siswa kelas X TAB di SMKN 2 Payakumbuh yang cukup kuat sebesar 0.569. Hal ini berarti bahwa dengan adanya kebiasaan belajar yang baik, maka hasil belajar siswa akan meningkat dan sikap belajar dan kebiasaan belajar berhubungan positif dan signifikan terhadap hasil belajar Teknologi Dasar Otomotif siswa kelas X TAB di SMKN 2 Payakumbuh yang kuat sebesar $0,785 \mathrm{Hal}$ ini berarti bahwa sikap belajar dan kebiasaan belajar dan hasil belajar secara bersama-sama bekorelasi terhadap hasil belajar anak.

Pembentukan sikap belajar menekan pada reaksi atau respon anak (Leonard \& U.S, 2010; Riwahyudin, 2015). Pada saat anak menunjukkan sikap belajar yang baik harusnya diberikan penguatan berupa hadiah ataupun perilaku yang menyenangka lama kelamaan anak akan meningkatkan sikap positifnya. Sikap belajar tidak dibentuk sejak lahir, melainkan dipelajari melalui pengalaman kesehariannya (Arif \& Samidjo, 2018; Wulandari \& Febriana, 2020). Sikap belajar juga dipengaruhi atas tiga komponen yang saling menunjang yaitu komponen kognitif, afektif dan konatif. Komponen kognitif yaitu representasi apa yang di percayai oleh individu pemilik sikap; komponen afektif, yaitu perasaan yang menyangkut emosional dan komponen konatif merupakan aspek kecendrungan berprilaku tertentu sesuai dengan sikap yang di miliki seseorang. Sikap menjadi pandangan yang dicerminkan melalui rasa senang atau tidak senang terhadap suatu objek yang dicerminkan melalui respon evaluatif. Respon evaluatif berarti bahwa bentuk reaksi yang dinyatakan sebagai sikap itu timbulnya didasari oleh proses evaluasi dalam diri individu yang memberi kesimpulan terhadap rangsangan dalam bentuk nilai baik-buruk, positif-negatif, menyenangkan-tidak menyenangkan, yang kemudian mengkristal sebagai potensi reaksi terhadap suatu objek. Jika yang timbul terhadap objek itu adalah perasaan senang, maka disebut sikap positif sedangkan kalau perasaan tak senang sikap negative.

Kontribusi kebiasaan belajar terhadap hasil juga sangat berpengaruh. Kebiasaan belajar merupakan factor penting dalam proses belajar. Kunci utama dari keberhasilan belajar siswa adalah kebiasaan belajar baik. Kebiasaan belajar yang baik akan membuat siswa memperoleh prestasi belajar yang tinggi (Magrifah, 2015; Rusmiyati, 2017). Suasana belajar yang baik merupakan suasana yang tepat dalam memahami apa yang sedang dipelajari oleh siswa tersebut, dengan begitu penguasaan terhadap suatu materi pelajaran akan semakin meningkat. Dalam rangka mencapai hasil belajar yang diharapkan, maka dalam kegiatan belajarnya siswa hendaknya mempunyai sikap dan cara belajar yang sistematis. Cara belajar yang baik adalah suatu kecakapan yang dimiliki 
oleh setiap siswa dengan jalan latihan dalam usaha belajarnya sehingga menjadi kebiasaan yang melekat pada diri siswa. Kebiasaan belajar sebagai perilaku siswa yang ditunjukkan secara berulang tanpa proses berpikir lagi dalam kegaitan belajar yang dilakukannya (Fasikhah, 2019; Hartuti, 2015). Pesiapan belajar dalam membentuk kebiasaan belajar yang baik yaitu (a) adanya tugas yang jelas dan tegas; (b) belajar membaca dengan baik;;(c) menggunakan metode keseluruhan dan sebagian; (d) mempelajari dan menguasai bagian-bagian yang sadar; (e) membuat outline danc atatan pada waktu belajar, (f) mengerjakan dan menjawab pertanyaan-pertanyaan, (g) menghubungkan bahan-bahan baru dengan bahan yang lama, (h) menggunakan berbagai sumber dalam belajar (mempelajari tabel, peta, grafik, gambar dan sebagainya dengan baik).

Penelitian ini sejalan dengan penelitian Arif \& Samidjo (2018) menyatakan bahwa ada hubungan yang positif dan signifikan sikap belajar dengan hasil belajar teknologi dasar otomotif. Wulandari \& Febriana (2020) menyatakan bahwa sikap belajar memiliki hubungan yang signifikan dengan hasil belajar. Jemudin, Makur, \& Ali (2019) menyatakan bahwa terdapat hubungan positif dan signifikan antara sikap belajar dengan prestasi belajar. Dapat disimpulkan bahwa sikap dan kebiasaan belajar siswa akan berpengaruh pada hasil dan prestasi siswa. Semakin baik sikap dan kebiasaan belajar siswa maka akan semakin baikpula hasil dan prestasi belajar siswa. Dapat disimpulkan faktor yang mempengaruhi hasil belajar siswa terdiri dari: kesehatan fisik, kelelahan, motivasi, minat, konsentrasi, natural curiousity, self-confidence, self-dicipline, intelegensi, ingatan, tempat, peralatan belajar, suasana, waktu belajar dan pergaulan.

Berdasarkan kesimpulan hasil penelitian, implikasi pada penelitian ini membuktikan bahwa ada kontribusi antara sikap belajar dan hasil belajar siswa. Sikap belajar berada dalam kategori cukup. Hal ini menunjukkan bahwa adanya peranan penting dari sikap belajar dalam meningkatkan hasil belajar. Dari segi kebiasaan belaajr terhadap hasil belajar juga terdapat hubungkan dengan kategori kuat. Sedangkan untuk hubungan antara sikap belajar dan kebiasaan belajar secara bersama-sama juga memiliki kontibusi terhadap hasil belajar Siswa di SMKN 2 Payakumbuh yang berada dikategori cukup.

\section{Simpulan}

Sikap belajar berhubungan positif terhadap hasil belajar mata pelajaran Teknologi Dasar Otomotif Siswa kelas X. Hal ini berarti bahwa sikap belajar yang baik akan mampu meningkatkan hasil belajar siswa. Kebiasaan belajar berhubungan positif dan signifikan terhadap hasil belajar. Hal ini berarti bahwa dengan adanya kebiasaan belajar yang baik, maka hasil belajar siswa akan meningkat. Hal ini berarti bahwa sikap belajar dan kebiasaan belajar dan hasil belajar secara bersama-sama bekorelasi terhadap hasil belajar anak.

\section{Daftar Pustaka}

Agathi Dian, I. A. A., Kristiantari, R. M. G., \& Ganing, N. (2015). Guru Terhadap Hasil Belajar Pengetahuan Bahasa Indonesia ( Keterampilan Membaca) Tema CitaCitaku Pada Siswa Kelas IV SD Desa Peguyangan. Mimbar PGSD Undiksha, 3(1). https://doi.org/http://dx.doi.org/10.23887/jjpgsd.v3i1.5172

Arif, L., \& Samidjo, S. (2018). Hubungan Antara Sikap Belajar Dan Motivasi Belajar Kejuruan Dengan Hasil Belajar Gambar Teknik. Jurnal Taman Vokasi, 6(1). https://doi.org/http://dx.doi.org/10.30738/jtv.v6i1.2865

Fasikhah. (2019). Hubungan Kebiasaan dan Disiplin Belajar dengan Hasil Belajar IPS. Scientific Journals, 1(3), 55-64. https://doi.org/https://doi.org/10.15294/jl.v9i1.39136 
Ferdian, A., Maryam, S., \& Selamat, I. N. (2018). Analisis Keslapan Belajar Siswa Kelas X Mipa Dalam Pembelajaran Kimia. Jurnal Pendidikan Kimia Undiksha, 2(1), 8. https://doi.org/10.23887/jjpk.v2i1.21177

Hartuti. (2015). Peran konsep diri, minat dan kebiasaan belajar peserta didik terhadap prestasi belajar fisika. Formatif: Jurnal IImiah Pendidikan MIPA, 5(2). https://doi.org/http://dx.doi.org/10.30998/formatif.v5i2.329

Izati, S. N., Wahyudi, \& Sugiyarti, M. (2018). Project Based Learning Berbasis Literasi untuk Meningkatkan Hasil Belajar Tematik. Jurnal Pendidikan: Teori, Penelitian, Dan Pengembangan, 3(9), 1122-1127-1127. https://doi.org/10.17977/jptpp.v3i9.11508

Jemudin, F. DE, Makur, A. P., \& Ali, F. A. (2019). Hubungan Sikap Belajar Dan Motivasi Belajar Terhadap Prestasi Belajar Matematika Siswa Smpn 6 Langke Rembong. Journal of Hanoi Math, 2(1). https://doi.org/https://doi.org/10.30862/jhm.v2i1.53

Junianto, D., \& Wagiran, W. (2013). Pengaruh kinerja mengajar guru, keterlibatan orang tua, aktualisasi diri dan motivasi berprestasi terhadap prestasi. Jurnal Pendidikan Vokasi, 3(3), 307-319. https://doi.org/10.21831/jpv.v3i3.1845

Kadek, J. (2017). Peningkatan Hasil Belajar Siswa Sekolah Dasar Melalui Aktivitas Pembelajaran Mengamati Berbantuan Audiovisual. International Journal of Elementary Education (IJEE), 1(3).

Kurnia, V. T., Damayani, A. T., \& Kiswoyo, K. (2019). Keefektifan Model Pembelajaran Number Head Together (NHT) Berbantu Media Puzzle Terhadap Hasil Belajar Matematika. Jurnal Ilmiah Sekolah Dasar, 192. https://doi.org/10.23887/jisd.v3i2.17772

Leonard, \& U.S, S. (2010). Pengaruh Konsep Diri, Sikap Siswa pada Matematika, dan Kecemasan Siswa terhadap Hasil Belajar Matematika. Cakrawala Pendidikan, 29(3), 341-352. https://doi.org/10.21831/cp.v3i3.362

Lestari, Kristiantari, \& Ganing. (2017). Pengaruh Model Pembelajaran Talking Stick Berbantuan Lagu Daerah Terhadap Hasil Belajar IPS. International Journal Of Elementary Education, $4(1)$. https://doi.org/http://dx.doi.org/10.23887/ijee.v1i4.12960.

Maesaroh, S. (2013). Peranan Metode Pembelajaran Terhadap Minat Dan Prestasi Belajar Pendidikan Agama Islam. Jurnal Kependidikan, 1(1). https://doi.org/https://doi.org/10.24090/jk.v1i1.536

Magrifah. (2015). Pengaruh Konsep Diri dan Kebiasaan Belajar Terhadap Hasil Belajar Matematika Siswa Kelas VIII SMP Negeri 6 Bontomantene. Mapan: Jurnal Matematika Dan Pembelajaran, 3(1). https://doi.org/https://doi.org/10.24252/mapan.2015v3n1a9

Nurlia, Hala, Muchtar, Jumadi, \& Taiyeb. (2017). Hubungan Antara Gaya Belajar, Kemandirian Belajar, Dan Minat Belajar Dengan Hasil Belajar Biologi Siswa. Jurnal Pendidikan Biologi, 6(2). https://doi.org/https://doi.org/10.24114/jpb.v6i2.6552

Rijal, S., \& Bachtiar, S. (2015). Hubungan antara Sikap, Kemandirian Belajar, dan Gaya Belajar dengan Hasil Belajar Kognitif Siswa. Jurnal Bioedukatika, 3(2), 15. https://doi.org/10.26555/bioedukatika.v3i2.4149

Riwahyudin, A. (2015). Pengaruh Sikap Siswa Dan Minat Belajar Siswa Terhadap Hasil Belajar Ipa Siswa Kelas V Sekolah Dasar Di Kabupaten Lamandau. JPD: Jurnal Pendidikan Dasar, 6, 11-23. https://doi.org/10.1017/CBO9781107415324.004

Rusmiyati, F. (2017). Pengaruh Kemandirian Dan Kebiasaan Belajar Terhadap Prestasi Belajar Metematika Siswa Kelas X Sma Negeri 1 Rongkop. UNION: Jurnal IImiah 
Pendidikan Matematika, 5(1), 77. https://doi.org/10.30738/.v5i1.931

Rustiana, E. R. (2011). Efek Psikologis dari Pendidikan Jasmani ditinjau dari Teori Neurosains dan Teori Kognitif Sosial. Media IImu Keolahragaan Indonesia, 1(2). https://doi.org/https://doi.org/10.15294/miki.v1i2.2035

Santra, Wibawa, \& Rati. (2018). Pengaruh Model Pembelajaran Think Pair Share Berbantuan Power Point Terhadap Hasil Belajar IPA. Jurnal IImiah Pendidikan Dan Pembelajaran PPs Universitas Pendidikan Ganesha, 2(1), 36-46. Retrieved from https://ejournal.undiksha.ac.id/index.php/lJEE/article/view/12962

Saputra, \& Andrizal. (2018). Pengaruh Motivasi Terhadap Hasil Belajar Siswa SMK. Jurnal Inovasi Vokasional Dan Teknologi, 18(1), 25-33. https://doi.org/https://doi.org/10.24036/invotek.v18i1.168

Sujana, I. W. C. (2019). Fungsi Dan Tujuan Pendidikan Indonesia. Adi Widya: Jurnal Pendidikan Dasar, 4(1), 29. https://doi.org/10.25078/aw.v4i1.927

Sutardi, \& Sugiharsono. (2016). Pengaruh Kompetensi Guru, Motivasi Belajar, Dan Lingkungan Keluarga Terhadap Hasil Belajar Mata Pelajaran Ekonomi. Jurnal Pendidikan IPS, 3(2), 188-198. https://doi.org/https://doi.org/10.21831/hsjpi.v3i2.8400

Sutrisno, V. L. P., \& Siswanto, B. T. (2016). Faktor-Faktor Yang Mempengaruhi Hasil Belajar Siswa Pada Pembelajaran Praktik Kelistrikan Otomotif Smk Di Kota Yogyakarta. Jurnal Pendidikan Vokasi. https://doi.org/10.21831/jpv.v6i1.8118

Usfandi. (2019). Pengaruh Konsep Diri, Minat Dan Sikap IImiah Siswa Terhadap Hasil Belajar Matematika. Pengaruh Konsep Diri, Minat Dan Sikap IImiah Siswa Terhadap Hasil Belajar Matematika. Pengaruh Konsep Diri, Minat Dan Sikap IImiah Siswa Terhadap Hasil Belajar Matematika, 8(2). Retrieved from https://journal.unnes.ac.id/sju/index.php/prisma/article/view/29261

Wulandari, M., \& Febriana, N. Y. (2020). Analisis Analisis Hubungan Sikap dengan Hasil Belajar Siswa di SMA Negeri 1 Sungai Penuh. Jurnal Pendidikan MIPA, 10(2). https://doi.org/https://doi.org/10.37630/jpm.v10i2.349

Yayuk, S., \& Sugiyono, S. (2019). Pengaruh kepemimpinan kepala sekolah dan biaya pendidikan terhadap kualitas proses belajar mengajar dan dampaknya dengan kompetensi lulusan SMK di kabupaten Gunungkidul. Jurnal Akuntabilitas Manajemen Pendidikan, 7(1), 84-96. https://doi.org/10.21831/amp.v7i1.23758

Yesiana, P. F., Gading, I. K., \& Riastini, P. N. (2016). Pengaruh Model Pembelajaran Make A Match Terhadap Hasil Belajar IPA Siswa Kelas V SD Negeri Gugus IV Kabupaten Buleleng Tahun Pelajaran 2016/2017. Mimbar PGSD Undiksha, 6(3), 1-11. https://doi.org/http://dx.doi.org/10.23887/jjpgsd.v5i2.10938

Zahro, F., Degeng, I. N. S., \& Mudiono, A. (2018). Pengaruh model pembelajaran student team achievement devision (STAD) dan mind mapping terhadap hasil belajar siswa kelas IV sekolah dasar. Premiere Educandum: Jurnal Pendidikan Dasar Dan Pembelajaran. https://doi.org/10.25273/pe.v8i2.3021 